\title{
PERSEPSI MASYARAKAT KOTA MEDAN TERHADAP PENGGUNAAN \\ FINANCIAL TECHNOLOGY (FINTECH)
}

\author{
Tri Inda Fadhila Rahma \\ tri.inda_fadhila@yahoo.com \\ Universitas Islam Negeri Sumatera Utara
}

\begin{abstract}
This research aimed to find out the public perception of the use of financial technology (Fintech). The informant in this research is the citizen of Medan as a user fintech or not. Data collection techniques by using in-depth interviews to 10 informants with different ages and professions background. The analysis technique by using descriptive qualitative method that is useful to provide facts and data. The result shows that public perception toward the use of financial technology (fintech) includes attitude, interest, understanding, motivation, and expectation. Where attitude of society towards the use of fintech, providing support to the progress of financial technology innovation in Indonesia is very helpful for the community, while the public interest to use fintech has been proven from interviews 9 out of 10 respondents have been interested by using it. The society has understood the benefits and usage of fintech because using fintech is more efficient and effective than other financial services so that people are motivated to use fintech. The society hope to the organizers of fintech in order to provide socialization to the public and practicality in using the service, so that people who lack understanding of technology can use it easily.
\end{abstract}

Keywords: Perception, Society, Public perception, Financial technology, online transportation

\footnotetext{
Abstrak

Penelitian ini bertujuan untuk mengetahui persepsi masyarakat terhadap penggunaan financial technology (Fintech). Informan dalam penelitian ini adalah informan pelaku, yaitu masyarakat Kota Medan yang menggunakan ataupun tidak menggunakan fintech. Teknik pengumpulan data menggunakan metode indepth interview kepada 10 informan dilatar belakangi usia dan profesi yang berbeda. Teknik analisa yang digunakan adalah metode deskriptif kualitatif yang berguna untuk memberikan fakta dan data. Hasil penelitian menunjukkan bahwa persepsi masyarakat terhadap penggunaan financial technology (fintech) meliputi sikap,
} 
minat, pemahaman, motivasi, dan harapan. Dimana sikap masyarakat terhadap penggunaan fintech, memberikan dukungan kepada kemajuan inovasi teknologi keuangan di Indonesia yang sangat membantu masyarakat, sedangkan minat masyarakat untuk menggunakan fintech sudah terbukti dari hasil wawancara 9 dari 10 responden sudah berminat menggunakannya. Masyarakat sudah begitu memahami manfaat dan penggunaan fintech karena penggunaan fintech lebih efisien dan efektif dibandingkan jasa keuangan lainnya sehingga masyarakat termotivasi untuk menggunakan fintech. Dan harapan masyarakat kepada penyelenggara fintech agar memberikan sosialisasi kepada masyarakat dan kemudahaan atau kepraktisan dalam menggunakan layanan, sehingga masyarakat yang kurang memahami teknologi dapat menggunakannya dengan mudah.

Kata Kunci : Persepsi, Masyarakat, Persepsi Masyarakat, Teknologi Finansial, dan Penggunaan Fintech

\section{Pendahuluan}

Teknologi merupakan alat mempermudah masyarakat dalam memanfaatkan sumber daya yang dibutuhkan. Dengan adanya teknologi, pemanfaatan terhadap sumber daya menjadi lebih mudah dan efesien. Hingga sekarang teknologi terus menyebarluas pada masyarakat, semakin banyak masyarakat yang sudah menikmati dan memanfaatkan teknologi. Salah satu teknologi yang semakin banyak dinikmati oleh masyarakat yakni penggunaan internet. Menurut Asosiasi Penyelenggara Jasa Internet Indonesia (APJII) mencatat bahwa mulai dari tahun 2014 sudah 88 juta orang pengguna sampai 132,7 juta orang Indonesia telah terhubung ke internet, karena perkembangan infrastruktur dan kemudahan mendapatkan smartphone atau perangkat genggam.

Melihat perkembangan internet yang semakin pesat digunakan oleh berbagai lapisan masyarakat, teknologi dan sistem informasi terus melahirkan berbagai inovasi, khususnya teknologi finansial untuk memenuhi berbagai kebutuhan masyarakat termasuk akses layanan finansial dan pemprosesan transaksi. Begitu halnya dengan layanan keuangan, semakin maraknya teknologi maka semakin mudah dan efesien masyarakat dalam memanfaatkan layanan keuangan. Penerapan teknologi dalam layanan keuangan sangat membantu 
masyarakat dalam bertransaksi, sehingga masyarakat yang belum bisa mengakses layanan keuangan dapat memanfaatkan finansial teknologi.

Kehadiran teknologi finansial sangat membantu masyarakat dalam mengakses produk-produk keuangan dan mempermudah melakukan transaksi keuangan dengan sentuhan teknologi di tangan. Dimanapun dan kapanpun masyarakat dapat melakukan transaksi tanpa harus datang langsung ke perusahaan financial atau mengantri dengan berbagai prosedur seperti perbankan pada umumnya. Hal ini dapat meningkatkan literasi keuangan di Indonesia.

Teknologi finansial (Financial Technology) disingkat atau disebut dengan TekFin atau Fintech. Teknologi Finansial dalam peraturan Bank Indonesia Nomor 19/12/PBI/2017 merupakan penggunaan teknologi sistem keuangan yang menghasilkan produk, layanan, teknologi, dan/atau model bisnis baru serta dapat berdampak pada stabilitas moneter, stabilitas sistem keuangan, efesiensi, kelancaran, kemananan dan keandalan sistem pembayaran. Penyelenggara teknologi finansial yakni meliputi sistem pembayaran, pendukung pasar, manajemen investasi dan manajemen resiko, pinjaman, pembiayaan dan penyedia modal, dan jasa finansial lainnya.

Fintech bukan merupakan layanan yang diberikan oleh perbankan melainkan model bisnis baru yang saat ini sangat membantu kebutuhan masyarakat. Jasa-jasa yang diberikan oleh perusahaan penyelenggara fintech membantu masyarakat dalam melaksanakan transaksi keuangan tanpa memiliki rekening seperti yang ada pada perbankan pada umumnya. Sehingga masyarakat tidak perlu menggunakan identitas pribadi dalam melaksanakan transaksi keuangan. Meskipun fintech bukan merupakan lembaga keuangan seperti perbankan namun fintech tetap diatur oleh Bank Indonesia agar konsumen atau masyarakat dapat terlindungi. Oleh karena itu perusahaan penyelenggara fintech wajib mendaftarkan perusahaannya pada Bank Indonesia ataupun Otoritas Jasa Keuangan.

Perusahaan penyelenggara fintech telah banyak berdiri di Indonesia dan dimanfaatkan oleh masyarakat. Namun hanya beberapa perusahaan yang telah resmi terdaftar dan mendapatkan izin dari Otoritas Jasa Keuangan. Hingga maret 2018, sebanyak 40 perusahaan penyelenggara layanan pinjam-meminjam uang 
berbasis teknologi informasi (fintech) yang telah resmi terdaftar. ${ }^{1}$ Sehingga masyarakat tidak perlu khawatir karena mendapatkan perlindungan konsumen dalam pemanfaatan jasa fintech di beberapa perusahaan yang telah resmi terdaftar tersebut.

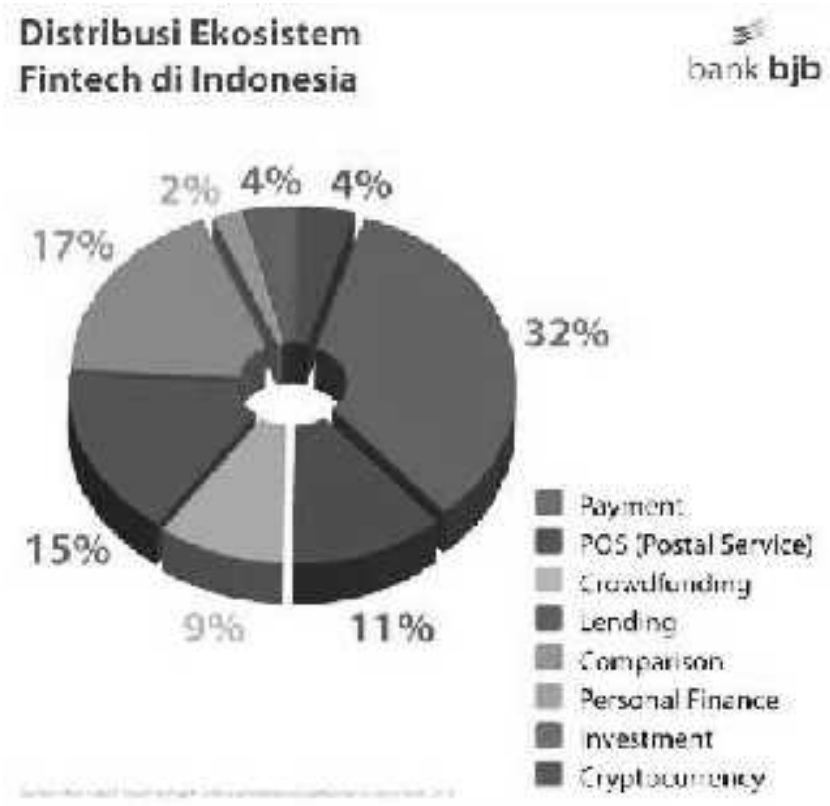

Sumber : Bank BJB tahun 2018.

\section{Gambar 1 Distribusi Ekosistem Fintech Di Indonesia}

Perusahaan fintech yang terdaftar dan dipisahkan dengan beberapa kategori menurut Bank Indonesia antara lain sistem pembayaran, pendukung pasar, manajemen investasi dan manajemen resiko, pinjaman, pembiayaan dan penyedian modal, dan jasa financial lainnya. Data di atas menujukkan bahwa kategori fintech yang paling banyak yaitu payment (sistem pembayaran) sebesar $32 \%$ dan kategori paling sedikit yakni personal finance.

Data Statista tahun 2017 melaporkan bahwa nilai transaksi fintech di Indonesia telah mencapai USD 15 miliar. Salah satu fintech yang sudah dinikmati oleh masyarakat yakni perusahaan starup berupa ojek online yang pembayarannya berupa go-pay maupun grab-pay. Jasa pembayaran yang dikenal dengan paytren, ovo, dll. Dilihat dari perkembangan data bahwa semakin banyak fintech yang hadir di Indonesia dan dapat dinikmati langsung oleh berbagai lapisan masyarakat. Dengan berbagai kemudahan-kemudahan penggunanannya, masyarakat tanpa menyadari telah menggunakan fintech dalam transaksi keuangannya. Sehingga menimbulkan persepsi masyarakat terhadap penggunaan fintech. Hal yang 
menimbulkan seseorang memberikan suatu persepsi ketika menggunakan atau mengkonsumsi sesuatu yakni berupa sikap, motivasi, minat, pengalaman dan harapan. Untuk itu, penulis bertujuan untuk melihat persepsi masyarakat terhadap penggunaan financial technology (fintech).

\section{Persepsi}

Persepsi merupakan penyerapan terhadap informasi melalui indera dengan melalui penglihatan, pendengaran, penciuman dan perasa. Dalam Kamus Besar Bahasa Indonesia kata persepsi memiliki arti tanggapan (penerimaan) langsung dari sesuatu. Menurut Sugiharto dkk bahwa persepsi adalah kemampuan otak dalam menerjemahkan stimulus atau proses untuk menerjemahkan stimulus yang masuk ke dalam alat indera manusia. Persepsi manusia terdapat perbedaan sudut pandang dalam penginderaan. Ada yang mempersepsikan sesuatu itu baik atau persepsi yang positif maupun persepsi negatif yang akan mempengaruhi tindakan manusia yang tampak atau nyata. ${ }^{2}$

Sedangkan menurut Bimo Walgito, persepsi merupakan suatu proses pengorganisasian, penginterpretasian terhadap stimulus yang diterima oleh organisme atau individu sehingga menjadi sesuatu yang berarti, dan merupakan aktivitas yang diintegrasi dalam diri individu. Respon sebagai akibat dari persepsi dapat diambil oleh individu dengan berbagai macam bentuk. Stimulus mana yang akan mendapatkan respon dari individu tergantung pada perhatian individu yang bersangkutan. Berdasarkan hal tersebut, perasaan, kemampuan berfikir, pengalaman-pengalaman yang dimiliki individu tidak sama, maka dalam mempersepsi sesuatu stimulus, hasil persepsi mungkin akan berbeda antar individu satu dengan individu lain. ${ }^{3}$

Dari beberapa pengertian di atas dapat disimpulkan bahwa persepsi adalah suatu proses menterjemahkan dari stimulus yang diterima oleh individu dan menghasilkan suatu tanggapan atau kesimpulan.

Stephen P. Robbins dan Timothy menyatakan bahwa faktor yang mempengaruhi seseorang memberikan suatu persepsi antara lain sebagai berikut: 
1. Sikap merupakan suatu reaksi yang terjadi pada seseorang yang mencerminkan suatu perasaan terhadap objek, aktivitas, peristiwa dan orang lain.

2. Motivasi yakni suatu faktor yang mendorong seseorang untuk melakukan suatu aktivitas tertentu, oleh karena itu motivasi sering diartikan sebagai faktor pendorong perilaku seseorang.

3. Minat yaitu dorongan atau keinginan untuk melakukan sesuatu

4. Pengalaman ialah peristiwa yang pernah dialami oleh seseorang sehingga memberikan suatu tanggapan terhadap objek tersebut.

5. Harapan merupakan sesuatu keyakinan atau kepercayaan terhadap sesuatu yang diinginkan akan didapatkan di masa yang akan datang.

\section{Masyarakat}

Masyarakat menurut kamus besar Bahasa Indonesia merupakan sekelompok manusia yang bertempat tinggal dalam suatu wilayah tertentu dengan batas-batas yang jelas dan menjadi faktor utamanya ialah adanya hubungan yang kuat di antara anggota kelompok dibandingkan hubungan dengan orang-orang diluar kelompoknya.

Dari pengertian di atas bahwa persepsi masyarakat adalah suatu proses yang terjadi pada sekelompok manusia yang hidup dan tinggal bersama dalam wilayah tertentu yang memberikan tanggapan atau kesimpulan terhadap hal-hal atau peristiwa yang diterima oleh sekelompok individu tersebut.

\section{Fintech}

Teknologi Finansial menurut peraturan Bank Indonesia Nomor 19/12/PBI/2017 adalah penggunaan teknologi sistem keuangan yang menghasilkan produk, layanan, teknologi, dan/atau model bisnis baru serta dapat berdampak pada stabilitas moneter, stabilitas sistem keuangan, efesiensi, kelancaran, kemananan dan keandalan sistem pembayaran. Penyelenggara teknologi finansial yakni meliputi sistem pembayaran, pendukung pasar, manajemen investasi dan manajemen resiko, pinjaman, pembiayaan dan penyedia modal, dan jasa finansial lainnya. 
Fungsi penyelenggara teknologi finansial dikategorikan ke dalam bagian sebagai berikut:

a. Sistem Pembayaran

Sistem pembayaran mencakup otorisasi, kliring, penyelesaian akhir dan pelaksaan pembayaran. Contoh penyelenggaraan teknologi finansial pada kategori system pembayaran antara lain penggunaan teknologi blockchain atau distributed ledger untuk penyelenggaraan transfer dana, uang elektronik, dan mobile payments.

b. Pendukung Pasar

Bahwa teknologi finansial yang menggunakan teknologi informasi dan/atau teknologi elektronik untuk memfasilitasi pemberian informasi yang lebih cepat atau lebih murah terkait dengan produk atau layanan jasa keuangan kepada masyarakat.

c. Manajemen Investasi dan Manajemen Resiko

Kategori manejemen investasi dan manajemen resiko antara lain penyediaan produk investasi online dan asuransi online.

d. Pinjaman (lending), Pembiayaan (financing atau funding), dan Penyediaan modal (capital raising)

Kategori tersebut antara lain layanan pinjam meminjam uang berbasis teknologi informasi (peer-to-peer lending) serta pembiayaan atau penggalangan dana berbasis teknologi informasi (crowd-funding).

e. Jasa Finansial lainnya

Jasa financial lainnya berupa selain sistem pembayaran, pendukung pasar, manajemen investasi dan manajemen risiko, serta pinjaman, pembiayaan dan penyediaan modal.

Teknologi Finansial memiliki beberapa kriteria yang ada pada perusahaan penyelenggara, antara lain sebagai berikut;

a. Bersifat inovatif,

b. Dapat berdampak pada produk, layanan, teknologi, dan model bisnis financial yang telah eksis,

c. Dapat memberikan manfaat bagi masyarakat, 
d. Dan dapat digunakan secara luas

Kewajiban yang harus dipatuhi oleh penyelanggara Teknologi Finansial yang terdaftar di Bank Indonesia yaitu sebagai berikut:

a. Menerapkan prinsip perlindungan konsumen sesuai dengan produk, layanan, teknologi, dan model bisnis yang dijalankan

b. Menjaga kerahasiaan data dan informasi konsumen termasuk data dan informasi transaksi antara lain dilakukan dengan mengelola dan menatausahakan dokumen transaksi dan konsumen secara baik dan tertib serta tidak memberikan data dan informasi transaksi dan konsumen kepada pihak lain kecuali atas persetujuan tertulis dari konsumen atau diwajibkan oleh ketentuan peraturan perundang-undangan.

c. Menerapkan prinsip manajemen risiko dan kehati-hatian, yakni telah melakukan identifikasi, pengukuran, pemantauan, dan pengendalian atas risiko yang mungkin timbul dalam kegiatan usahanya.

d. Menggunakan rupiah dalam setiap transaksi yang dilakukan di wilayah Negara Kesatuan Republik Indonesia sesuai dengan ketentuan peraturan perundang-undangan yang mengatur mengenai mata uang.

e. Menerapkan prinsip anti pencucian uang dan pencegahan pendanaan terorisme sesuai dengan perundang-undangan.

f. Memenuhi ketentuan peraturan perundang-undangan lainnya antara lain peraturan mengenai pendirian badan hukum serta penyelenggaraan sistem dan transaksi elektronik.

g. Dilarang melakukan kegiatan system pembayaran dengan menggunakan virtual currency. Virtual currency ialah uang digital yang diterbitkan oleh pihak selain otoritas moneter yang diperoleh dengan cara mining, pembelian atau transfer pemberian (reward). Virtual currency bukan merupakan alat pembayaran yang sah di Indonesia.

\section{Konsumsi}

Konsumsi merupakan kegiatan menggunakan barang dan jasa untuk memenuhi kebutuhan hidup. Konsumsi adalah semua penggunaan barang dan jasa yang dilakukan manusia untuk memenuhi kebutuhan hidupnya. Barang dan jasa yang digunakan dalam proses produksi tidak termasuk konsumsi, karena barang 
dan jasa itu tidak digunakan untuk memenuhi kebutuhan hidup manusia. Barang dan jasa dalam proses produksi ini digunakan untuk memproduksi barang lain. ${ }^{4}$

Dalam ekonomi Islam konsumsi dikendalikan oleh lima prinsip dasar sebagai berikut: ${ }^{5}$

\section{a. Prinsip Keadilan}

Syarat ini mengandung arti ganda yang penting mengenai mencari rezeki secara halal dan tidak dilarang hukum. Dalam soal makanan dan minuman, yang terlarang adalah darah, daging binatnag yang telah mati sendiri, daging babi, dan daging binatang yang ketika disembelih diserukan nama selain Allah.

\section{b. Prinsip Kebersihan}

Syarat yang kedua ini tercantum dalam Al-Qur'an maupun As-Sunnah tentang makanan. Harus baik atau cocok untuk dimakan, tidak kotor ataupun menjijikkan sehingga merusak selera. Karena itu, tidak semua yang diperkenankan boleh dimakan dan diminum dalam semua keadaan. Dari semua yang diperbolehkan makan dan minumlah yang bersih dan bermanfaat.

\section{c. Prinsip Kesederhanaan}

Prinsip ini mengatur perilaku manusia mengenai makanan dan minuman adalah sikap tidak berlebih-lebihan, yang berarti janganlah makan secara berlebih.

\section{d. Prinsip Kemurahan Hati}

Dengan mentaati perintah Islam tidak ada bahaya maupun dosa ketika kita memakan dan meminum makanan halal yang disediakan Tuhan karena kemutahan hati-Nya. Selama maksudnya adalah untuk kelangsungan hidup dan kesehatan yang lebih baik dengan tujuan menunaikan perintah Tuhan dengan keimanan yang kuat dalam tuntunanNya, dan perbuatan adil sesuai dengan itu, yang menjamin persesuaian bagi semua perintah-Nya.

\section{e. Prinsip Moralitas}

Bukan hanya mengenai makan dan minuman langsung tetapi dengan tujuan terakhirnya, yakni untuk peningkatan atau kemajuan nilai-nilai moral dan spiritual. Seorang mslim diajarkan untuk menyebut nama Allah sebelum makan 
dan menyatakan terima kasih kepada-Nya setelah makan. Dengan demikian ia akan merasakan kehadiran Ilahi pada waktu memenuhi keinginan-keinginan fisiknya. Hal ini penting artinya karena Islam menghendaki perpaduan nilai-nilai hidp material dan spiritual yang berbahagia.

Berkaitan dengan perilaku konsumen ada tiga variabel dalam mempelajarinya, yaitu variabel stimulus, variabel respons, dan variable antara. ${ }^{6}$

a. Variabel Stimulus

Variabel stimulus merupakan variabel yang berada di luar diri individu (faktor eksternal) yang sangat berpengaruh dalam proses pembelian. Contohnya: merk dan jenis barang, iklan, pramuniaga, penataan barang, dan ruangan.

b. Variabel Respons.

Variabel respons merupakan hasil aktivitas individu sebagai reaksi dari variabel stimulus. Variabel respons sangat bergantung pada faktor individu dan kekuatan stimulus. Contohnya: keputusan membeli barang, pemberi penilaian terhdap barang, perubahan sikap terhadap suatu produk.

c. Variabel Intervening.

Variabel intervening adalah variabel antara stimulus dan respons. Variabel ini merupakan faktor internal individu termasuk motif membeli, sikap terhadap suatu peristiwa, dan persepsi terhadap suatu barang.

\section{Model Konseptual}

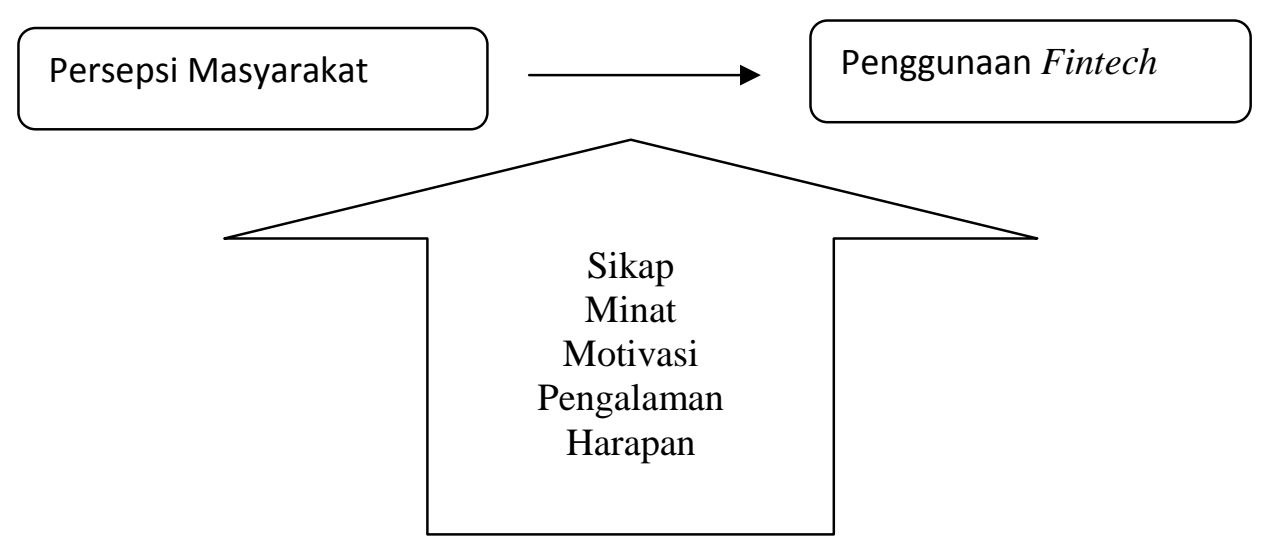




\section{Metodologi Penelitian}

Jenis penelitian penelitian ini menggunakan metode penelitian kualitatif. ${ }^{7}$ Dengan teknik pengumpulan data dalam penelitian dengan menggunakan wawancara yakni mengajukan pertanyaan kepada informan secara tatap muka, maka dari wawancara tersebut akan diperoleh hasil dari tanya jawab oleh informan yang nantinya akan menjadi data dalam penelitian. Informan penelitian adalah orang yang memberikan informasi baik tentang dirinya ataupun orang lain atau suatu kejadian maupun suatu hal kepada peneliti. ${ }^{8}$ Peneliti memilih teknik purposive sampling yaitu menetapkan kriteria yang dipenuhi oleh informan sebelum melakukan penelitian. Maka kategori informan dalam penelitian ini ialah informan pelaku, yaitu masyarakat Kota Medan yang menggunakan ataupun tidak menggunakan fintech, kemudian diurutkan berdasarkan usia dan profesi. Sebagaimana sasaran dalam penelitian ini untuk melihat persepsi informan terhadap penggunaan fintech. Analisis data dalam penelitian ini akan dianalisis menggunakan teknik analisis interaktif yang dikemukan oleh Miles dan Huberman Punch, bahwa teknik ini terdiri dari tiga komponen yaitu: ${ }^{9}$

a. Reduksi data (data reduction) yang mempunyai tiga tahap, yakni tahap pertama yaitu editing, pengelompokkan dan peringkasan data, tahap kedua yaitu penyusunan catatan-catatan tentang berbagai hal yang berkaitan dengan unit analisis, sehingga peneliti dapat menemukan tema-tema dan pola-pola data, dan tahap ketiga yaitu konseptualisasi tema-tema dan pola-pola data;

b. Penyajian data (display), yaitu pengorganisasian data dengan menjalin atau mengaitkan kelompok data yang satu dengan kelompok data yang lain, sehingga seluruh data dapat dianalisis dalam sebuah kesatuan;

c. Penarikan atau pengujian kesimpulan (drawing and verifying conclusion), yaitu pengimplementasian prinsip induktif dengan mempertimbangkan polapola data yang ada dan atau kecenderungan dari data display yang telah disusun.

\section{Hasil Penelitian dan Pembahasan}

Karakteristik Informan yang menggunakan fintech di Kota Medan berkaitan dengan usia mereka dapat digambarkan pada tabel sebagai berikut. 
Tabel 1. Karakteristik Responden Menurut Usia

\begin{tabular}{|c|c|}
\hline Usia & Jumlah Per Orang \\
\hline $18-20$ Tahun & 1 \\
\hline $21-30$ Tahun & $\mathbf{7}$ \\
\hline $31-40$ Tahun & 2 \\
\hline Total & $\mathbf{1 0}$ \\
\hline
\end{tabular}

Sumber: Data primer diolah, 2018

Data di atas menunjukkan gambaran distribusi frekuensi berkaitan dengan usia responden yang menggunakan fintech, jumlah responden terbanyak adalah yang berusia antara 21-30 tahun sebanyak 7 orang. Kemudian diikuti oleh informan yang berusia antara 31-40 tahun sebanyak 2 orang. Sedangkan sisanya berusia antara 18-20 tahun sebanyak 1 orang. Hasil ini mengindikasikan bahwa konsumen yang menggunakan fintech kebanyakan berusia dewasa yaitu 21-30 tahun, hal ini dimungkinkan karena pada usia tersebut, merupakan usia produktif.

Karakteristik informan yang menggunakan fintech di Kota Medan berkaitan dengan pekerjaan mereka dapat digambarkan pada tabel sebagai berikut.

Tabel 2. Karakteristik Responden Menurut Pekerjaan

\begin{tabular}{|c|c|}
\hline Pekerjaan & Jumlah Per Orang \\
\hline Pelajar / Mahasiswa & 2 \\
\hline Swasta / Wiraswasta & 6 \\
\hline Pegawai Negeri Sipil (PNS) & 1 \\
\hline Ibu Rumah Tangga & 0 \\
\hline Total & 10 \\
\hline
\end{tabular}

Sumber : Data primer diolah, 2018 
Data di atas menunjukkan gambaran distribusi frekuensi berkaitan dengan pekerjaan informan yang menggunakan fintech, frekuensi terbanyak adalah informan yang berprofesi sebagai Swasta atau Wiraswasta sebanyak 6 orang. Kemudian diikuti oleh profesi mahasiswa sebanyak 2 orang serta lainnya yaitu PNS sebanyak 2 orang.

\section{Deskriptif Hasil Penelitian}

Analisis data secara deskriptif ini mendeskripsikan hasil analisis terhadap informan dengan cara menguraikan tanggapan dari 10 responden berkaitan dengan persepsi masyarakat Kota Medan terhadap penggunaan fintech berdasarkan data dari hasil wawancara yang telah dilakukan dimana peneliti menggunakan metode kualitatif dan pendekatan deskriptif. Dalam pembahasan penelitian ini akan menjelaskan, memaparkan, serta menggambarkan data yang telah diperoleh oleh peniliti melalui wawancara secara mendalam (in-depth interview) yang dilakukan kepada para informan. Adapun deskripsi informan penelitian ini, yaitu:

\section{1) Fahry Riswal Manurung, 40 Tahun, PNS}

Informan yang pertama sering menggunakan jasa fintech, fintech yang digunakan oleh informan ini adalah kategori sistem pembayaran. Salah satu aplikasi yang digunakan oleh informan yaitu OVO, Gopay, dan Grabpay. Informan mengutarakan persepsinya terhadap penggunaan fintech bahwa fintech memudahkan dalam melakukan transaksi keuangan dan memiliki banyak promopromo menarik perhatian. Hal yang menyebabkan informan menggunakan jasa tersebut dikarenakan fintech lebih efektif dan efesien sehingga dalam bertransaksi dengan sentuhan tangan lebih praktis dan dapat menghemat waktu serta tenaga tanpa pembayaran uang tunai. Namun, informan masih ragu menggunakan kategori fintech lainnya selain sistem pembayaran karena alasan keamanan produk yang ditakutkan penyalahgunaan produk oleh oknum yang melakukan kecurangan.

2) Amos Yowatan Aritonang, 23 Tahun, Mahasiswa

Informan yang kedua hampir setiap hari menggunakan jasa fintech, fintech yang digunakan oleh informan ini adalah kategori sistem pembayaran. Salah satu 
aplikasi yang digunakan oleh informan yaitu OVO. Informan mengutarakan persepsinya terhadap penggunaan fintech bahwa memanfaatkan jasa fintech dapat meminimalisir penggunaan uang tunai, sehingga lebih cepat dan efesien dalam bertransaksi. Harapannya terhadap perusahaan fintech ialah agar dapat memperluas produk yang sesuai dengan kebutuhan masyarakat dan menggabungkan kategori yang berbeda-beda menjadi satu kategori.

3) Kurnia Ramadhan, 39 Tahun, Wiraswasta

Informan yang ketiga belum pernah menggunakan jasa fintech. Informan ketiga sering mendengar penawaran-penawaran menarik dari fintech, namun hal itu tidak memotivasi beliau untuk menggunakan jasa tersebut. Hal ini dikarenakan beliau seorang pekerja swasta yang kebutuhannya terhadap jasa keuangan masih jarang atau tidak sama sekali. Informan mengutarakan persepsinya terhadap fintech bahwa kehadiran fintech sangat membuat perhatian masyarakat, namun fintech belum cukup memenuhi kebutuhannya sehingga informan belum tertarik menggunakan fintech.

4) Edy Syahputra Harahap, 27 Tahun, Wiraswasta

Informan yang keempat sering menggunakan jasa fintech, fintech yang digunakan oleh informan ini adalah kategori sistem pembayaran. Salah satu aplikasi yang digunakan oleh informan yaitu OVO. Informan sering menggunakan pada saat ingin berbelanja dan makan di cafe atau restaurant. Informan mengutarakan persepsinya terhadap penggunaan fintech bahwa menggunakan jasa fintech sangat menguntungkan karena banyak diskon-diskon yang ditawarkan, sehingga membuat informan tertarik menggunakan jasa tersebut. Harapan informan agar produk-produk yang ditawarkan oleh perusahaan fintech meliputi semua bidang baik kesehatan maupun pendidikan. Dan harapannya agar fintech dapat mudah ditemukan ditempat-tempat perbelanjaan manapun untuk melakukan transaksi.

\section{5) Kristina Sipayung, 24 Tahun, Mahasiswa}

Informan yang kelima merupakan mahasiswa yang sering menggunakan jasa fintech, fintech yang digunakan oleh informan ini adalah kategori sistem pembayaran. Informan mengutarakan persepsinya terhadap penggunaan fintech 
bahwa informan terbantu dengan kehadiran fintech di Indonesia, karena memudahkan dan melancarkan transaksi keuangan informan, tetapi informan bingung karena banyak perusahaan fintech yang menawarkan jasa-jasa keuangan yang menarik perhatian, harapannya agar perusahaan yang digunakan hanya satu dan memiliki banyak produk yang dibutuhkan.

6) Aprilla, 27 Tahun, Wiraswasta

Informan yang keenam jarang menggunakan jasa fintech, fintech yang digunakan oleh informan ini adalah kategori sistem pembayaran. Informan mengutarakan persepsinya terhadap penggunaan fintech bahwa penggunaan jasa fintech membuat informan boros karena mudahnya melakukan transaksi keuangan, sehingga membuat informan menjadi loss control. Harapannya terhadap fintech di Indonesia agar produk-produk yang ada pada fintech sudah mencakup banyak produk untuk semua transaksi ekonomi.

7) Dessy Wiriani, 25 Tahun, Wiraswasta

Informan yang keenam jarang menggunakan jasa fintech, fintech yang digunakan oleh informan ini adalah kategori sistem pembayaran. Layanan fintech yang sudah digunakan informan yaitu untuk transaksi pembayaran belanja konsumsi dan transaksi pembayaran rumah tangga seperti bayar listrik, pulsa dan air tidak perlu direpotkan dengan mendatangi tempat-tempat pembayaran, informan hanya cukup membuka smartphone dan dapat melakukan pembayaran dimanapun dan kapanpun. Informan mengutarakan persepsinya terhadap penggunaan fintech bahwa kurangnya sosialisasi fintech ke daerah terpencil, sehingga kegunaan atau manfaat fintech belum dapat dirasakan oleh seluruh lapisan masyarakat. Masih banyak masyarakat yang belum mengetahui keberadaan fintech dan manfaat fintech pada umumnya. Padahal menurut informan, keberadaan fintech sangat membantu informan dalam melakukan transaksi keuangan, jika dimanfaatkan oleh seluruh lapisan masyarakat maka masyarakat lain juga akan ikut merasakan kemudahan melakukan transaksi keuangan hanya dengan melalui jaringan teknologi yang dapat dimanfaatkan. Maka dalam melakukan transaksi keuangan menjadi jauh lebih efektif dan efesien 
tanpa harus datang ke lembaga keuangan layaknya perbankan dan harus menunggu antrian panjang agar dapat terlayani.

8) Nursantri Yanti, 28 Tahun, Tenaga Pendidik/ Wiraswasta

Informan yang kedelapan merupakan tenaga pendidik yang jarang memanfaat jasa fintech, fintech yang digunakan oleh informan ini adalah kategori sistem pembayaran. Informan mengutarakan persepsinya terhadap penggunaan fintech bahwa penggunaan fintech dapat membuat transaksi keuangan menjadi efektif, namun keefektifannya dalam memudahkan transaksi tidak selalu efektif dan efesien karena ketika menjadikan fintech pilihan yang tepat maka penggunaan fintech akan menjadi efektif. Namun fintech harus dapat menyesuaikan penggunaan aplikasinya dengan kesetaraan kemampuan setiap lapisan masyarakat, agar penggunaan semakin mudah dan tidak terjadi kesenjangan antara seorang ahli teknologi dengan yang kurang mengetahui pemanfaaatan teknologi.

9) Humairah Al- As'ari, 27 Tahun, Guru

Informan yang kesembilan merupakan guru yang sering memanfaatkan jasa fintech, fintech yang sering digunakan oleh informan ini adalah kategori sistem pembayaran. Informan hampir setiap hari memanfaatkan jasa fintech dalam bertransaksi ojek online dan belanja dengan aplikasi seperti OVO. Informan mengutarakan persepsinya terhadap penggunaan fintech bahwa dengan adanya fintech bertransaksi lebih menguntungkan dibandingkan dengan melakukan pembayaran secara tunai, selain membayar lebih murah informan juga dapat menikmati jasa tersebut tanpa harus menunggu kembalian uang tunai, sehingga proses transaksi lebih cepat. Semakin meningkatnya perkembangan teknologi semakin teknologi dapat dinikmati oleh setiap lapisan masyarakat. Informan belum menggunakan fintech dengan kategori lain karena masih belum percaya dan belum tau bahwa perusahaan fintech yang sudah terdaftar di OJK memiliki perlindungan konsumen. Harapan informan kepada perusahaan fintech agar meningkatkan keamanan dan membatasi pengguna agar tidak terjadi penyalahgunaan kemudahan penggunaan fintech.

10) Novita Muldiana Putri, 20 Tahun, Mahasiswa 
Informan yang kesepuluh merupakan mahasiswa yang sering memanfaatkan jasa fintech, fintech yang sering digunakan oleh informan ini adalah kategori sistem pembayaran. Informan hampir setiap hari memanfaatkan ojek online, dan menurut informan bahwa menggunakan fintech jauh lebih menguntungkan daripada melakukan pembayaran dengan uang tunai. Informan mengutarakan persepsinya terhadap penggunaan fintech bahwa informan senang karena potongan harga yang diberikan perusahaan memberikan keuntungan para pengguna khususnya informan.

Fintech merupakan inovasi keuangan model terbaru yang hadir ditengahtengah masyarakat, agar masyarakat dapat menikmati transaksi keuangan yang lebih modern dan mudah dengan menggunakan teknologi internet ataupun smartphone. Masyarakat yang saat ini mulai ketergantungan terhadap internet ataupun smartphone menjadi peluang pasar bagi perusahaan-perusahaan fintech. Keberadaan fintech telah memberikan kemudahan masyarakat dalam melakukan proses transaksi keuangan, sehingga menimbulkan sikap masyarakat untuk mendukung adanya keberadaan fintech dan kemudian merasa senang menggunakan layanan tersebut. Fintech telah banyak hadir di Indonesia dan masyarakat Kota Medan khususnya sebagian besar sudah menikmati, hal ini dapat dilihat dari hasil wawancara 10 responden bahwa 9 dari 10 responden yang sudah memanfaatkan atau menggunakan layanan fintech, dalam arti bahwa persepsi masyarakat terhadap minat untuk menggunakan fintech sudah mulai terpenuhi karena ketertarikan masyarakat untuk memanfaatkannya.

Namun 1 diantaranya belum memanfaatkan layanan tersebut. Alasan informan belum menggunakan layanan tersebut dikarenakan kurangnya pemahaman dan ketiadaan pengalaman informan terhadap penggunaan dan manfaat fintech. Oleh karena itu, hal ini menunjukkan bahwa salah satu persepsi masyarakat berkaitan dengan harapan menyatakan perlunya sosialisasi lebih mendalam kepada para masyarakat agar semua lapisan masyarakat dapat mengetahui dan memanfaatkan layanan tersebut. Selain itu hal yang perlu diperhatikan oleh para penyelenggara fintech ialah kemudahaan atau kepraktisan dalam menggunakan layanan, sehingga masyarakat yang kurang memahami teknologi dapat menggunakannya dengan mudah. 
Penggunaan fintech juga dipengaruhi oleh bagaimana persepsi mereka terhadap strata sosial ekonomi yang terbentuk yakni faktor lingkungan. Menurut hasil wawancara bahwa kategori fintech yang digunakan para responden ialah sistem pembayaran, karena lingkungan sekitar Kota Medan sudah dapat menggunakan mobile payment untuk melakukan transaksi pembayaran sehingga mendukung penggunaannya. Hal ini mendukung data bank BJB tentang distribusi ekosistem fintech di Indonesia bahwa kategori fintech yang paling banyak yaitu payment (sistem pembayaran) sebesar 32\%. Sedangkan kategori lain belum peneliti temukan selama mendapatkan informasi para informan. Seperti yang disebutkan oleh informan yang bernama Fachry dan Humairah bahwa adanya keraguan penggunaan kategori fintech lain dikarenakan meragukan akan keamanan penggunaannya. Sehingga perlunya sosialiasi mengenai Ketentuan Bank Indonesia mengenai penyelenggaraan teknologi finansial (fintech) bahwa konsumen sudah terlindungi karena adanya peraturan yang berlaku, agar masyarakat yakin dan percaya kepada perusahaan-perusahaan penyelenggara fintech serta berkeinginan untuk mencoba menggunakan layanan fintech dengan kategori lainnya.

Kelebihan fintech yang diperoleh dari hasil wawancara bahwa dengan menggunakan layanan fintech, para informan merasa lebih efektif dan efesien dalam melakukan transaksi keuangan khususnya dalam transaksi pembayaran. Selain mempermudah tanpa menggunakan uang tunai, para informan juga merasakan keuntungan-keuntungan yang diperoleh dari penyelenggara fintech. Dalam hal ini penyelenggara fintech tersebut telah berhasil menarik perhatian konsumen dengan berbagai promo atau diskon yang ada. Dapat disimpulkan bahwa layanan fintech yang efektif dan efesien menjadi motivasi para informan untuk menggunakan layanan tersebut.

\section{Kesimpulan}

Keberadaan fintech yang menjadikan inovasi keuangan model terbaru di Indonesia khususnya di Kota Medan telah memberikan kemudahan masyarakat dalam melakukan proses transaksi keuangan, sehingga menimbulkan sikap masyarakat untuk mendukung adanya keberadaan fintech dan kemudian merasa senang menggunakan layanan tersebut. Pemahaman masyarakat terhadap penggunaan fintech dari hasil wawancara menunjukkan bahwa 9 dari 10 informan 
sudah mengetahui tentang fintech dan memahami cara penggunaan serta manfaat layanan yang diberikan oleh layanan fintech.

Masyarakat sudah mulai tertarik untuk menggunakan fintech dilihat dari pemaparan 10 informan, 9 diantaranya sudah memanfaatkan atau menggunakan layanan dengan kategori sistem pembayaran. Masyarakat telah termotivasi untuk menggunakan fintech karena penggunaannya yang efektif dan efesien. Sehingga masyarakat mendapatkan keuntungan dalam penggunaannya. Dan masyarakat mengharapkan sosialisasi para penyelenggara fintech dan kemudahaan atau kepraktisan dalam menggunakan layanan, sehingga masyarakat yang kurang memahami teknologi dapat menggunakannya dengan mudah.

Adapun penulis menyarankan untuk perusahaan penyelenggara fintech agar memberikan sosialisasi kepada masyarakat agar lebih dikenal oleh masyarakat, serta memperbaiki lebih baik layanan produk sehingga dapat dengan mudah digunakan, dan menjaga keamanan pengguna agar terhindari dari penyalahgunaan. Dan untuk peneliti selanjutnya agar menjadikan variabel faktorfaktor yang mempengaruhi persepsi masyarakat dengan pendekatan kauntitatif, sehingga mendapatkan kesimpulan yang lebih menguatkan persepsi masyarakat terhadap penggunaan fintech.

\section{Catatan Akhir}

${ }^{1}$ www.ojk.go.id

${ }^{2}$ Sugiharto, dkk, Psikologi Pendidikan, (Yogyakarta: UNY Press, 2007), hal. 8

${ }^{3}$ Bimo Walgito, Pengantar Psikologi Umum, (Jkakarta: Penerbit Andi, 2004), hal. 70

${ }^{4}$ Michael James, Pembangunan Ekonomi di Dunia Ketiga, (Jakarta: Ghalia, 2001), hal. 49.

${ }^{5}$ Eko Suprayitno, Ekonomi Islam (Yogyakarta: Graha Ilmu, 2005), 94-95.

${ }^{6}$ Ismail Nawawi, Isu-Isu Ekonomi Islam: Kompilasi Pemikiran Filsafat dan Teori Menuju Praktik di Tengah Arus Ekonomi Global, (Jakarta: VIV Press, 2013), hal. 233

${ }^{7}$ Sugiyono. Analisis Kualitatif. (Bandung : Alfabeta, 2010), hal. 15

${ }^{8}$ Afrizal, Metode Penelitian Kualitatif, (Jakarta: Rajagrafindo Persada, 2014), hal. 139

${ }^{9}$ Pawito, Penelitian Komunikasi Kualitatif. (Yogyakarta: PT LKIS Pelangi Aksara, 2008), hal. 104 
$661 \mid$ At-Tawassuth, Vol. III, No. 1, 2018: 642 - 661

\section{Daftar Pustaka}

Afrizal. Metode Penelitian Kualitatif. Jakarta: Rajagrafindo Persada. 2014.

James, Michael. Pembangunan Ekonomi di Dunia Ketiga. Jakarta: Ghalia. 2001.

Nawawi, Ismail. Isu-Isu Ekonomi Islam: Kompilasi Pemikiran Filsafat dan Teori Menuju Praktik di Tengah Arus Ekonomi Global. Jakarta: VIV Press. 2013.

Pawito, Penelitian Komunikasi Kualitatif. Yogyakarta: PT LKIS Pelangi Aksara. 2008.

Sugiharto, dkk. Psikologi Pendidikan. Yogyakarta: UNY Press. 2007.

Sugiyono. Analisis Kualitatif. Bandung : Alfabeta. 2010.

Suprayitno, Eko. Ekonomi Islam. Yogyakarta: Graha Ilmu. 2005.

Walgito, Bimo. Pengantar Psikologi Umum. Jakarta: Penerbit Andi. 2004.

www.ojk.go.id 